\title{
IUELTAL
}

\section{EFL Teachers' Perceptions: Challenges and Coping Strategies of Integrated Skills Approach (ISA) Implementation at Senior High Schools in Aceh}

\author{
Saiful Akmal \\ Department of English Language Education, \\ Universitas Islam Negeri Ar-Raniry, Banda Aceh, Indonesia \\ saiful.akmal@ar-raniry.ac.id
}

\section{Yuliar Masna}

Department of English Language Education,

Universitas Islam Negeri Ar-Raniry, Banda Aceh, Indonesia yuliarmasna@gmail.com

\section{Mutiara Tria}

Department of English Language Education, Universitas Islam Negeri Ar-Raniry, Banda Aceh, Indonesia mutiaratria@gmail.com

\section{Titin Arifa Maulida}

Department of English Language Education, Universitas Islam Negeri Ar-Raniry, Banda Aceh, Indonesia titinarifa57@gmail.com

\begin{abstract}
:
Integrated Skills Approach (henceforth ISA) is valuably considered to practice all language skills simultaneously with wide and various activities offered to expose learners to the real communicative purpose. This research aims to find out teachers' perceptions of challenges and coping strategies in implementing ISA at their respective schools. The research participants were chosen by using purposive sampling, in which the information towards six English teachers from different Senior High School in Banda Aceh and Aceh Besar by using unstructured interviews. The findings revealed that generally, most teachers had positive
\end{abstract}


perceptions towards ISA. Only one teacher's face constrains in applying ISA. Furthermore, the teachers also faced challenges in applying integrated skills approach in the classroom, those are; students' lack of vocabulary, school environment and facilities, and teachers' difficulties in designing activity/material. Nevertheless, the teachers have their strategies to cope with those challenges such as; enriching vocabulary through flashcards, grouping students randomly, preparing their own material and equipment, motivating them by giving interesting short movies and games and expanding their knowledge more about integrated skills approach.

Keywords: challenges, coping strategies, EFL teachers, Integrated Skills Approach (ISA), perceptions

\section{Introduction}

\subsection{Background}

There are three circle use of English described by Kachru (1992) they are; first language, second language, and foreign language. Those are namely the inner, the outer and the expanding circles. Canagarajah and Said (2010) praised Kachru categorization as the attempt to pluralize English Language Teaching to the outer and expanding circles. The world-wide use of English has given the way of redefining a more globalized understanding of English or Englishes (Edwards \& Laporte, 2015; Monfared \& Khatib, 2018) and also to the linguistic innovation on how to creatively learn English (Deshors et al., 2016).

Learning English as a second language entails special attention on four basic language skills. These four basic skilss (reading, listening, speaking, writing) have to be addressed by teachers to help students develop their communcative competence gradually (Sadiku, 2015). Hinkel (2006, as cited in Gautam, 2019) proposes "the concept 'communicative competence' introduced in the pedagogical realm brought a remarkable change in the perspective on how language skill were to be taught and used for communication inside and outside of the classroom". As results are many strategies, methods and approaches in optimizing English teaching in the classroom are applied. Nowadays, as stated by Renau (2016), "English language lessons try to fulfill students' needs for communication by using different strategies and methodologies". Teachers feel it is valuable to integrate the language skills, and it can enhance student's communication competence, otherwise, the hope for student-centred learning in the classroom would not be achieved and it would eventually lead to limited responses and lack of communication in the classroom (Huda \& Lubis, 2019).

When students learn a language, they will not only apply the understanding of the concept of the language, but they will also be able to use it in their daily life (Hashim \& Yunus, 2018). Teaching and learning English is a success when students are able to competently use the English language skills inside and outside the classroom (Jenkins, 2012). In order to gain a more successful learning, teachers and academic communities have to actively participate in the effort of teaching learning strategies (Tanjung, 2018). Therefore, the curriculum revisit should take into account both the English teachers' perception and authentic assessment (Mardjuki, 2018), in the form of integrating the four main skills of the English language. 
Four main skills of English; listening, speaking, reading, and writing are considered as prior significant since tremendous investigation on ELT started (Lander \& Brown, 2007). Nan (2018) reports that "the development of any of four skills depends on and can lead to the development of the rest and finally causes the improvement of overall language ability". Teachers will have the chance to develop more assortment into the lesson and create a wider range of activities by integrating skills (Tavil, 2010), and help the process of language acquisition faster than before (Akram \& Malik, 2010)

Many researchers believe that outside the classroom is the place where students use the language to communicate and to participate in activities (Leung, 2013; Lopriore, L., \& Vettorel, 2015). As stated by Choi and Nunan (2018) "beyond the classroom, learners are not only activating their language in authentic contexts, they are also developing their communicative repertoires and acquiring language skills that are not readily acquired in the classroom". The integration of skills fulfils students' diverse learning styles integrating skills also supports the students to learn English willingly and comfortably. Another point is that, as argued by Aydogan and Akbarov (2014) "the integrated skill approach confronts English language learners to authentic language and challenges the learners to interact naturally in the language". Moreover, realistic and operative class communication is then hypothetically coming from the integration of the four language skills, where teachers need to design a good classroom atmosphere, suitable activities, cultivate students and handle the problems responsively (Davies, \& Pearse, 2000). In a similar tone, Derbel and Mohammadi (2015) add that language skills integration must be accompanied with cultural sensitivity too.

The four language skills (listening, speaking, reading, and writing) are the form in which language is used for communication (Richards \& Schmidt, 2002). All of these languages skills fusion are employed when a person communicates using a language. In oral pattern people communicate when they receive the messages by listening and respond by speaking. In written language, people receive communicate by written form and the messages delivered by reading and responds by writing. In short, depending on the channel of communication, a person listens, speaks, reads and writes. Thus, language skills are a means of communication in integrative approaches and interdisciplinary perspectives (Spector, 2015). A person receive information as an input by listening and reading, and output of language is produce by employing speaking and writing regarding on the language inputs they receive. That has explained why currently the trend of introducing ISA into study program curriculums is increasingly becoming more and more popular (Deneme \& Ada, 2010; Dewiyanti, 2015; Lee, et al., 2010; MacVaugh, et al., 2014).

Integrated skills approach (ISA) is thus believed as a valuable way to teach EFL students in order to have realistic communication. "Integrated-skills is based on the concept that in natural, day-to-day experience, oral and written languages are not kept separate and isolated from one another" (Su, 2007). Instead, they often occur together, integrated in specific communication events (Peregoy \& Boyle, 2001). This approach is consistent with the communicative language teaching as it emphasizes meaningful and authentic language use and link oral and written language development.

Roberts and Kellough (2000), defined integration in the teaching and learning as designing the instructional program for interrelating the discrete disciplines of subject matter in an applicable design which can achieve effective learning. Oxford (2001) claimed that teaching 
by integrating skills is supposed to be an effectual strategy for language learning entirely. To achieve these objectives, the integrative language skills instruction appears to be the most efficacious way to teach language in order to achieve motivating and realistic communication (Brown, 2005; Tsung-Yuan \& Oxford, 2002).

\subsection{Rationales}

Although ISA has been extensively researched, most of the earlier researches discussed the effectiveness of using integrated skills in the classroom according to the learner's perspective. Moreover, Su (2007), who observed students' views of integrated-skills approach in Taiwan's EFL college classes found that the integration of four skills will assist the teacher to provide broader learning source and various class activities (Hinkel, 2006), besides ISA allow student to have written and spoken absolute integration of four language skills. Nanda, Harahap and Damayanti, (2019) also researched about the problem faced by English department students in the integrated course (covers four language skills in English) in the Indonesian context. The research shows that students face problems in learning grammar, and find difficulty in grammar application in speaking and finding new words when reading English texts.

\subsection{Research Questions}

ISA is considered an important approach that helps teachers to create dynamic lessons, involve the pupils in diverse learning events and exchanges. ISA will create abundant chances for students to engage in the learning process and increase their motivation to learn English. However, previous studies indicated that discrepancy between learners' and teachers' views about the implementation of ISA in the classroom. Thus, by conducting this research, we would like by exploring the following set of research questions:

(1) How do teachers' perceive on the implementation of ISA in the classroom?

(2) What are teachers' challenges in applying ISA in the classroom?

(3) How do they cope the challenges that teachers faced in practicing ISA?

\section{Literature Review}

\subsection{Integrated Skills Approach (ISA)}

ISA is one of many approaches in ELT which is believed as a valuable way to teach students in to have real communication skills. "Integrated-skills is based on the concept that in natural, day-to-day experience, oral and written languages are not kept separate and isolated from one another" (Su, 2007). Instead, they frequently take place simultaneously and included in detailed communication proceedings (Peregoy \& Boyle, 2001). This is consistent with the communicative language teaching approach as both focus on meaningful and authentic language use, as well as linking oral and written language development at the same time. The four language skills (listening, speaking, reading, and writing) are the form in which language is utilized for communicative purposes (Richards \& Schmidt, 2002). A person receives information as input by listening and reading, and the output of language is produced by employing speaking and writing regarding the language inputs they receive. Thus all skills should be integrated to give students learning experience with realistic communication in (at the discourse level) where students able to use the language skills they have in everyday life (Rymes, 2015). 


\subsection{Types of ISA}

ISA and its teaching are differentiated into four types: content-based language teaching, task-based language teaching, project-based learning, and problem-based learning. Let us start with the first type, Communicative Language Teaching (CLT). CLT talks about two things: the communicative commitments for which students use the target language (e.g., making introduction, invitation, greeting, interviewing, etc.) and the use of subject matters for second/foreign language teaching objectives. Additionally, in content-based language teaching, a subject is promoted as a fundamental element to consolidate language skills. In other words, language skills are intertwisted around the collective subject being learned (Brown, 2005; Robson, 2002)

Second, Task-Based Language Teaching (TBLT) is in agreement with a student-centred educational philosophy (Nunan, 2004; Richards \& Rodgers, 2001). TBLT consists of certain constituents such as the objective, method, specific outcome (Murphy, 2003; Nunan, 2004; Skehan, 2001). The student engages in a communicative task in the target language when learning. There are two general forms of language learning tasks that teachers could use to fit in language skills according to Richards \& Rodgers (2001) and Kondo-Brown (2005), those are pedagogic/academic tasks and real/actual-world tasks.

Third, Project-Based learning (PBL) is a learning methodology which considered as studentcentred approach too (Grant, 2002), PBL "involves students to design, solve the problem, make a decision and work independently" (Thomas, 2000). They will create "work by solving the real problem" (McGrath, 2002). Project-based learning also can establish "fun" and "flexible learning" (Doppelt, 2003; Klein, et.al., 2009).

Fourth, Problem-Based Learning (PBL) is an instructional method where students learn to solve problems. The problems that will be solved are authentic tasks in social and contextual student's teamwork. The students will rely on prior information on the problem, categorize evidence they prerequisite to know how to "enhance the learning transfer", and the strategies to solve the "authentic problem" and to unlock students' "academic potential" (Gallagher \& Gallagher, 2013; Hung, 2013; Marra, et.al., 2014).

\section{Research Methodology}

\subsection{Rationales for the Methods}

This qualitative research uses the grounded theory approach following (Corbin \& Strauss, 2008; Urquhart, 2012) as it is a good method to analyse data and build a practical theory from the data of social research. Furthermore, the data were collected through unstructured or in-depth or open-ended interviews. This type of interview allows a more meaningful reflection on the data by using the inductive approach.

\subsection{Participants and Ethical Consideration}

The participants are six teachers from different senior high schools in Banda Aceh and Aceh Besar. They are purposively selected by deciding the benchmarks for selection, either included or excluded in the study (Etikan, Musa \& Alkassim, 2016). The benchmarks are: 1) the teachers shall represent and teach either in Banda Aceh or Aceh Besar, 2) experienced English teachers attested by a minimum of 10 years teaching assignment, 3) graduated from the English Language Department, or more importantly 4) they have the experience and understanding towards ISA implementations in the classroom. Since this research used in-depth interview the researchers only prepare three topics regarding ISA. The interview 
process is recorded and materials that could be used during the interview process include tape recorder and paper (note-taking back up mechanism). Each participant has approximately 45 minutes for the interview.

Moreover, each senior high school only has four or three English teachers, meaning that the school selection is based on one school one representative by taking into account that the schools should be state public schools from each district/city, regardless of their gender. The selected participant from these senior high schools are; one representative from SMKN Penerbangan Banda Aceh, one Senior High School 3 Banda Aceh, one Senior High School 1 Banda Aceh Jeumpa Puteh, one from Senior High School Modal Bangsa Aceh Besar, one from Senior High School 1 Darul Imarah Aceh Besar, and one from MAN 2 Aceh Besar.

\subsection{Data Analysis Procedures}

The data were analysed by coding. Saldaña (2015) and Gibbs (2007) propose that coding is classifying the text to found an outline of ideas about the study. In this study, three stages were used by the researcher to analyse the data of the interview. The information then examined through open coding techniques (Blair, 2015), or line-by-line analysis (Klassen, et.al. 2012), to detect provisional explanatory concepts. Then we do the axial coding to relate the conceptions and groupings by specifying their sizes and then finding the link between the two (Bell, 2014). Finally, in selective coding, where the overarching different topics developed from the date were classified into core categories linked to the research questions, i.e., teachers' perceptions, challenges and coping strategies of practicing ISA.

\section{Findings}

\subsection{Teacher Perception of ISA}

\subsubsection{Simultaneous Use of Skills}

Almost all of the participants said that the ISA class was very helpful for teachers to use language in real communication rather than in segregated contexts. ISA encourages students to use both main and additional skills i.e., grammar, punctuation, and pronunciation. Thus, the ISA approach to incorporate the four skills of English such as Listening, Speaking, Reading and Writing at the same time is very advantageous for English Foreign Language classroom. It is reasonably understood that with ISA, language is taught by encouraging a communicative way of teaching. As participant 1 said:

Yes, I think ISA is very much encouraging students to engage, so the teachers ask questions, the students listen. So in listening, then they answer the question and speaking, and then make conclusion from the reading passage, then ask them to write. So even if we are discussing reading but four skills integrated simultaneously.

The statement above is proven by Roberts and Kellough (2000) idea. They understand integration in teaching and learning as the process of designing the instructional platform to relate different skills of a subject matter in applicable learning design.

I think it's also difficult to separate the skills, at least two receptive or productive skills in language teaching need to be addressed, so they have to be able oral and written. Integrated skills are automatically taking place.

Based on participant 3 statement above, it can be concluded that it is very natural that when it comes to integrating skills approach, the skills will be combined as expected when we use the language in everyday communication and it seems impossible to separate the skills. Su 
(2007) furthermore explains: "Integrated-skills are based on the concept that in natural, day-to-day experience, oral and written languages are not kept separate and isolated from one another. Instead, they often occur together, integrated with specific communication events" (Peregoy \& Boyle, 2001).

\subsubsection{More Enjoyable Teaching}

The participants agreed that it was more enjoyable for the teachers to use ISA. The integrated approach allows learners to relate appropriately and accomplish a higher level of motivation to learn a language. Thus, students can be motivated to learn a language if they can use it communicatively, instead of just to have knowledge. This is as participant 4 said:

I think this integrated skill is very advantageous and more enjoyable for me because it can cover all skills that you teach to your students. As far as I know I am experiencing it when I teach the students. The students are so eager to learn, because you can present something like we call comfortability in learning, especially when you bring those activities to your students, they will welcome you. I let them enjoy the activity that I give to them and I promote it to them according to what they want. So I think that's what we call integrated skills.

Based on the statement above the integrative language skill teaching appears to be the most valuable way to teach language to achieve realistic communication (Kondo-Brown, 2005; Oxford, 2001; Tsung-Yuan \& Oxford, 2002).

\subsubsection{Increase Leaners' Enthusiasm}

Since ISA tends to focus on language use rather than on the knowledge, some students who are not interested in learning English are very enthusiastic to engage in learning activities created by the teachers. Those students willingly learn as participant 5 stated:

Because it helps the teachers to make the teaching-learning more successful, sometimes integrated skills can be used to help some students who don't like English.

After trying it, they like it and excited to learn and when I practice ISA they won't sleep in the class anymore.

ISA will give teachers the opportunity to broaden the way of learning, so learners have more enthusiasm when teachers provide them with various activities. That is what makes them has willing to learn more. Participant 6 also had the same perception as participant 5 . He thought that:

If you ask them to listen only, maybe they will get bored, then ask them to write, and if they don't like writing, especially my students, ask them to speak, and also to read, but when we applied ISA in one go, someone who does not have confidence in writing will have another chance to engage in other activities.

Both statements from participants 5 and 6 are supported by what Oxford (2001) explained that ISA is supposed to be an effective strategy for language learning as a whole.

\section{1. 4. More Dynamic and Exciting Classroom Environment}

Since ISA let teachers perform several skills, students will get involved and responsible for their own learning. They will feel more comfortable participating. Participant 4 believed:

Yes of course, because the integrated skills mean that this is not a single activity, there is some activity that I can combine there and then we try to propose the students with 
different kinds of activity. Because it is not a stiff or boring method. You can do anything here ... so dynamic.

This voice is echoed by Richard-Amato (1996, as cited in Tajzad \& Namaghi, 2014) "skills integration creates a dynamic and exciting classroom environment". Several activities provided by teachers could be varied and interesting for students, thus the learning environment would change into exciting real communication.

\subsubsection{Project Activity}

Moreover, ISA provides students the opportunity to have real communication outside the classroom. By doing group work, they will enhance language skills with fun yet insightful activities and projects.

In descriptive text material, I ask students to visit a historical place, divided them into a group, I ask them to visit Museum Aceh and tsunami and tried to find out interesting things to describe then give me the report in writing also present in front of the class and their friends ask them some questions In addition, I ask them to make short-video. For example the material is about songs, ask them to make video how to sing a song, moral value of the song and also with the movies, when we have news item material I ask them to make the video as if they are a news anchor so the students feel exited to learn English.

In addition, participant 4 uttered:

l ever tried to bring the biology subject into their writing in my classroom, the project is maybe repetitive and it has been introduced by other teachers but I ask them to write that in English, so I think that the project is not conducted by me, but the student has done that and they want to implement that in English subject so I tried to integrate it because, English very general, I think they can include all of the materials they got from all the teachers and then they can do it in English with me. So it doesn't mean that if we call for project, the students must have their own project with the teachers but we can integrate it with any subjects in school.

The participant believes that giving students the project was one of the resourceful activities in ISA. As stated by Sands and Solomon (2003) "when students are challenged to get to work solving real-life problems, the whole world becomes a classroom".

\section{2. Teachers' Challenges on ISA Implementation}

\subsubsection{Students' Poor Vocabulary}

Most participants approved that it is hard for them to apply ISA in the classroom smoothly because some students have low motivation in learning English and they have poor competence in English. As participant 6 said:

I think the challenges are the very old thing that is vocabulary.

In addition, participant 3 said:

the big challenges - this is not only for me, but I think for all the teachers is students vocabulary, sometimes zero when they enter Senior high School on senior high school. Actually they should master about 1000 words. Surprisingly some students even cannot count one to ten, then what? That is the challenge, but still, I integrated skills little by little. 
Students' factors may hinder ISA operation are often related to students' poor language and vocabulary problems, and undesirable defiance towards their teachers and friends may impede ISA implementation (Oxford, 2001; Richards \& Rodgers, 2001)

\subsubsection{Learning environment and facilities}

Learning environment and facilities are two things that would support ISA running well, as participant 5 understood:

We do not have any laboratory and we can't practice listening by using the lab, because it is under construction. So here, all things are still very messy.

School climate, policy, and equipment in the school environment can be blamed as the scapegoat of bad ISA implementation. To achieve the success of ISA implementation, the school should provide a facilitative learning atmosphere, facilitate sufficient instructional and adequate authentic materials to support learning such as books, photocopy machines, LCD, computer projectors, internet connection, etc.

\subsubsection{Time-Consuming and Difficulties in Designing Activity/Material}

The participant realized that it was difficult sometimes to apply integrated skills due to some reasons such as difficulties in time management. As participant 1 expressed that:

Sometimes, if I want to apply ISA, but it is time-consuming when we want to apply this we run out of time, and it is taking so much effort for me to prepare and design the material and activities.

Coyle (2007) addresses that four skills incorporation can be perplexing for teacher, because it takes a decent comprehension of discourse and the skills of using textbook adaptably. It can also be time-consuming as it needs lot of preparations to choose materials and to plan projects and activities.

\subsection{Teachers' Strategies to Cope with Challenges}

The participants approved that there are several ways to cope with their difficulties and challenges in applying ISA in the classroom. Some teachers have the same way to cope with their challenges in ISA class, they are; enriching vocabulary through flashcards, grouping students randomly, preparing their material and equipment, motivating them by giving interesting short movies and games and expanding their knowledge more about integrated skills approach.

\subsubsection{Vocabulary Enrichment through Flashcards}

As participant 3 experienced, she used flashcard for her students to improve their vocabulary. She believed that flashcards will help her to cope with her challenges because as far as she observed, the use of flashcards can help students understand and memorize vocabulary faster than just memorize it traditionally. Moreover, her students like to practice flashcards because it is easier as it normally equipped with visualization on the card. As participant 3 said:

I used flashcard to overcome my challenges. The speed is ten times faster than memorizing because there is visualization so it is easier for learners to acquire new vocabularies.

Participant 3 experiences she tends to agree that the teaching of oral performance, for instance, learning vocabulary with flashcards is usually to effective to improve students' 
vocabulary mastery, as flashcards are mostly focused on mastery sight of words (Ruwe, et.al, 2011).

\subsubsection{Group Work}

Grouping students will be the best way to cope with ISA implementation in the classroom. Some of them believe that due to students' different levels of proficiency, they will work collaboratively in group work. Thus it is a good way to address them in the group; especially for helping some students with a lack of English knowledge. As participant 4 understood:

I overcome the challenges by making some groups. So put them into several groups randomly and every student has a task to do and discuss, I think because all of the friends doing the task willingly or collaboratively as well.

Based on participant 4 statement, grouping students and give them a task to do and discuss, they will work cooperatively in a group and will help each other. "The rationale of using group work of classroom arrangement is that learners have more opportunities to interact ..., as compared with a one-on-one exchange between teachers and learners" (McDonough, Shaw \& Masuhara, 2013). "Affective factors such as motivation may also be positively influenced by such learner's modes" (McDonough, Shaw \& Masuhara, 2013). Akmal, Dahliana \& Fadhila, 2019) believe that cooperative works and assessment between educators and students can be beneficial to the process of ELT.

\subsubsection{Bringing Personal Equipment}

Teachers who face challenges in facilities like having no laboratory or listening room in their school will bring their speakers to teach their students. Authentic materials also supported learning in the classroom (Sari, 2017). As participant 5 held:

I like to bring my speaker, my laptop and material because we can't use it. We don't have it in school yet, or we have it, but we cannot get access to it.

In addition participant 6 maintained:

We do not have listening's room in our school, but still, I can bring my speaker, laptop and stuff to facilitate them having listening activity.

Participant 5 explains that she creatively considered this as challenges, thus she did this by putting more effort to bring her equipment to make the listening practice in her classroom.

\subsubsection{Providing interesting short movies and games.}

One of the ways to overcome the challenges faced by the teacher is by giving and showing short movies and playing interesting games to motivate them. As participant 6 said:

Consider that my school is located in rural-area, I would like to encourage them to love English first, because it considerably fun and I am trying to get some interesting games, short-movie related to learning English.

Base on participant 6 experience, they will be motivated first to love English because even though applying ISA in the classroom will give many advantages, but still, if the student's is lacking basic English skills, it will be difficult to teach the students in this way. King (2002) assumes that: "it is refreshing learning experience for students who need to take break from rote learning of endless English vocabulary and drill practices, and replace it with something realistic, a dimension that is missing in the textbook-oriented teaching". It is important to motivate students through the enjoyable way if they have a good motivation to learn, at least ISA implementation would be fun for students. 


\subsubsection{Expanding teachers' knowledge on ISA}

All of the participants agreed that ISA is very advantageous in teaching, and they believe that it is important for them to improve their knowledge about ISA through some readings, workshops and seminars. As participant 5 proposed:

For me, I have to learn much more. I have to find more method technique in teachinglearning English because I like to have active students in the class, I have got to find out and read a lot about ISA and how to implement that in the teaching-learning process for the students and also for myself,

Based on teacher's perceptions, it is important to overcome their challenges in the classroom. English teachers may not have satisfactory familiarity and abilities to carry out ISA. As Richards and Rodgers (2001) mentioned that teachers may accept that it is unmanageable to teach more than one language skills simultaneously. Thus, teachers are recommended to participate in any of activity that can help them to expand their knowledge about ISA.

\subsection{Discussion}

The finding of this present study suggests that participants had a positive perception of ISA implementation in the classroom. This finding confirms Tajzad and Namaghi (2014) suggestion that learners are enthusiastically accepting ISA in learning English and moreover recommended continuing to implement ISA in the classroom (SU, 2007). ISA, thus, increases learners' enthusiasm and self-assurance, cognitive competence, reduces their anxiety, involves students in communication, boosts concurrent use of all language skills, provides the learners with reflection time and re-conceptualizes teachers' role (Poon, 2011; Yang, 2011). This is also in line with Deneme \& Ada (2010) finding that by applying an intergrated skill approach a better communication and coherent teaching would be achieved. Moreover Su (2007), also puts out similar findings that ISA will give instructor opportunity to provided extended learning sources and various class activities, and able to interact in written and spoken absolute integration of four language skills. It is agreed that through this approach teachers will have a lot spaces to monitor and evaluate students' progress in developing their multiple skills at the same time (Oxford, 2001).

Participants believed that ISA was an enjoyable and exciting approach that they have ever applied. They also believe that the activities and materials in the class may encouraged and motivated students to engage in the classroom. This finding is in line with by Adeyemi (2010, as cited in Yimwilai, 2015) stating that integrated approach presents a greater place for students to get a more comprehensive learning in the classroom which is meaningful, interesting, and enjoyable. However, teachers also faced challenges and difficulties in students' lack of vocabulary and proficiency and difficulties in designing the activity and material of ISA as well. Maleki (2010, as cited in Sevy-Biloon, 2018) suggested that in the integrated approach, to achieve communication competence, teachers need to consider various kinds of communicative activities incorporated into a language classroom. ISA implementation allows teachers to reflect and then provide various enjoyable and fun learning activities for students which embrace all of the student's active participation in the learning process. This is supported by Pysarchyk and Yamshynska (2015) reporting that through integrating skills teachers are possible to develop students' language skills to show their communication competence relying on a written or an oral text, and succeed in academic communication. However, rregarding the obstacles in applying ISA, teachers 
were able to cope with any difficulties of ISA in the classroom, by employing certain strategies such as enriching vocabulary through flashcards, grouping students randomly, preparing their material and equipment, motivating them by giving interesting short movie and game. As asserted by Tuncay (2014), students would be autonomous and able to develop their critical thinking since relative components and media are integrated into the lessons. In this regard, therefore teachers believed that they need to read more about the integrated skills approach.

Despite its great potentials and advantages it offers, some factors can hinder the integrated language skills teaching approach. Plakans (2012) outlined that high-quality development of ISA can be the real challenges for its growing use worldwide. Meanwhile Kebede (2014) also distinguished three groups of integrated language skills teaching approach hampering factors: teachers, schools, and learners' factors as explained below:

\section{a. Teachers' Factors}

The factors that possibly hinder ISA implementation are teacher perception towards ISA itself, it is related to teachers' competence and belief. English teachers may think that it is much easier to simplify the language teaching in the classroom, rather than more than one language skills at a time. As Richards and Rodgers (2001) mentioned that teachers may assume that it is instructionally impossible to teach more than one language skills at a time. Similar tones were also voiced by other researchers. For language teachers, ISA may pose some restrictions too. Since it requires teachers to be well-trained on using the approach, ISA implementation is deemed to be inefficient because more time should be provided on teacher preparation and teacher training aspects (Mekheimer, 2011). Some countries in Southeast Asia, such as Malaysia, hereafter learned that the use of ISA means that they should allocate more time to improve teachers' understanding and practice towards thematic approach to teach student integrated living skills (Min, Rashid \& Nazri, 2012). Another issue is that some subjects and skills were better taught with ISA. Aydogan \& Akbarov (2014) for example revealed that writing and speaking skills as well as vocabulary subject have significantly improved after the introduction of ISA. As a result, focus on reading skills and other English learning subjects are relatively untouched.

\section{b. School's Factors}

According to Pardede (2019) school have a potential in deterring ISA implementation regarding to the climate, policy, and equipment. In order to achieve a success learning or success implementation of ISA, the school should provide a facilitative learning atmosphere as a symbol of strong institutional support. In relation to this, the school should provide enough instructional materials and equipment, and others authentic materials which able to support learning such as books, photocopy machine, LCD, computers projector, internet connection, and so on. In addition, the classroom environment needs to be comfortable and could be easily set up to design interesting activities. In most cases, the expectation on ISA is very high and this suggests that school ICT and curriculum related to ISA must be well provided (Eisenberg, Johnson \& Berkowitz, 2010). Lewallen, et al. (2015) even promoted a whole intervention for schools to link with the community for improving student's achievement and developments. In the word of Fink (2013), school and college should enable the significant learning experiences for students to be inserted in the curriculum design if they want a successful ISA implementation. 


\section{c. Students Factors}

Students' factors that may hinder the integrated language skills teaching approach are related to their motivation, attitudes and language proficiency. Students with low motivation, very poor language proficiency, and negative attitude towards their teachers and/or peers may hamper integrated language skills teaching (Oxford, 2001; Richards, 2001). In this light, some believe that different models of classroom management model, student engagement combined with interesting instructional technology may decide the success of ISA implementation (Davies, et al., 2013; Zepke \& Leach, 2010). Abdrabo (2014) asserts that ISA-like approach is important for student to decide when to teach and practice in second language acquisition contexts.

\section{Conclusion}

\subsection{Summary}

They agreed it was advantageous both for teachers and students. ISA lets students practice all language skills simultaneously; as a result, teachers provided various and enjoyable activities in the classroom. One of six participants told that ISA implementation little bit difficult to apply due to some reasons, such as context and learning material. However, all teachers believe that applying ISA in the classroom can increase students' enthusiast and active participation in the learning process since the activities are enjoyable and exciting. ISA implementation in the classroom helps teachers to ease their work in assessing students' skills. They also agreed that applying ISA in the classroom encourages students' competence in English. Students are encouraged to use and practice all skills simultaneously in the classroom. Teachers also think ISA implementation created a more dynamic and exciting learning environment.

\subsection{Limitations and Implications for Future Studies}

There are still many aspects that can be analysed about the integrated skills approach. Considering to the fact of our limited samples of Indonesian high school context, future elaborations on more extensive samples are recommended to the impact of ISA implementation on teachers. Future studies on ISA may also consider that comparing the impact between students and lecturers is very much feasible to be conducted. However, the result of this study may be used as initial information to conduct further researches on those suggested topics.

\section{References}

Abdrabo, N. (2014). Integrated-skills approach: Teaching vs. practice in 12 acquisition. Language Institute Foreign Language Center (DLIFLC).

Akmal, S., Dahliana, S., \& Fadhila, R. (2019). Cooperative Assessment Writing Practices In An Acehnese Private University: Helping Or Troubling? JL3T (Journal of Linguistics, Literature and Language Teaching), 5(2), 107-119.

Akram, A.,\& Malik, A. (2010). Integration of language learning skills in second language acquisition. International Journal of Art and Sciences, 3(14), 231-240. https://doi.org/10.5901/mjss.2014.v5ngp672

Aydogan, H.,\& Akbarov, A, A. (2014). The Four Basic Language Skills, Whole Language 
\&amp; Intergrated Skill Approach in Mainstream University Classrooms in Turkey. Mediterranean Journal of Social Sciences, 5(9), 672-680. https://doi.org/10.5901/mjss.2014.v5n9p672

Bell, E. E. (2014). Graduating Black Males: A Generic Qualitative Study. Qualitative Report. 19(13), 1-10. http://www.nova.edu/ssss/QR/QR19/bell13.pdf

Blair, E. (2015). A reflexive exploration of two qualitative data coding techniques. Journal of Methods and Measurement in the Social Sciences, 6(1), 14-29.

Canagarajah, A. S., \& Said, S. B. (2010). English language teaching in the outer and expanding circles. Routledge.

Choi, J., \& Nunan, D. (2018). Language learning and activation in and beyond the classroom. Australian Journal of Applied Linguistics, 1(2), 49-63.

Corbin, J., \& Strauss, A. (2008). Basics of qualitative research: Techniques and procedures for developing grounded theory (3 rd). SAGE.

Coyle, D. (2007). Content and language integrated learning: Towards a connected research agenda for CLIL pedagogies. International Journal of Bilingual Education and Bilingualism, 10(5), 543-562.

Davies, P. \& Pearse, E. (2000). Success in English teaching. Oxford University Press.

Davies, R. S., Dean, D. L., \& Ball, N. (2013). Flipping the classroom and instructional technology integration in a college-level information systems spreadsheet course. Educational Technology Research and Development, 61(4), 563-580. https://doi.org/10.1007/s11423-013-9305-6

Deneme, S., \& Ada, S. (2010). An application of skills integration in language teaching. Language in India, 10(9), 9-18.

Derbel, E. M. I. R. A., \& Al-Mohammadi, S. (2015). Integration of Language Skills and Culture In English Language Teaching: Rationale And Implications For Practice. In R. A.-M. \& C. Denman (Ed.), Issues in English education in the Arab world. Cambridge Shcolars Publishing.

Deshors, S. C., Götz, S., \& Laporte, S. (2016). Linguistic innovations in EFL and ESL. International Journal of Learner Corpus Research, 2(2), 131-150. https://doi.org/10.1075/ijlcr.2.2.01des

Doppelt, Y. (2003). Implementation and assessment of project-based learning in a flexible environment. International Journal of Technology and Design Education, 13(3), 255-272.

Edwards, A., \& Laporte, S. (2015). Outer and expanding circle Englishes: The competing roles of norm orientation and proficiency levels. English World-Wide, 36(2), 135-169. https://doi.org/10.1075/eww.36.2.01edw

Etikan, I., Musa, S. A., \& Alkassim, R. S. (2016). Comparison of convenience sampling and purposive sampling. American Journal of Theoretical and Applied Statistics, 5(1), 1-4.

Gallagher, S. A., \& Gallagher, J. J. (2013). Using Problem-based Learning to Explore Unseen Academic Potential. Interdisciplinary Journal of Problem-Based Learning, 7(1), 111-131. https://doi.org/10.7771/1541-5015.1322

Gautam, P. (2019). Integrated and Segregated Teaching of Language Skills: An Exploration. Journal of NELTA Gandaki, 1, 100-107. https://doi.org/10.3126/jong.viio.24464

Gibbs, G. (2007). American journal of theoretical and applied statistics. SAGE.

Grant, M. M. (2002). Getting a grip on project-based learning: Theory, cases and recommendations. Meridian: A Middle School Computer Technologies Journal, 5(1), 1-17. Hashim, H. U., \& Yunus, M. M. (2018). English as a Second Language (ESL) Learning: 
Setting the Right Environment for Second Language Acquisition. Tadris: Jurnal Keguruan Dan Ilmu Tarbiyah, 3(2), 207. https://doi.org/10.24042/tadris.v3i2.2941

Hinkel, E. (2006). Current perspectives on teaching the four skills. TESOL Quarterly, 40(1), 109-131.

Huda, M., \& Lubis, A. H. (2019). Exploring the Implementation of Student-centered Learning in EFL Classrooms: Perspectives from Islamic Secondary-school Teachers in Indonesia. IJELTAL (Indonesian Journal of English Language Teaching and Applied Linguistics), 3(2), 187-201.

Hung, W. (2013). Problem-Based Learning: A Learning Environment for Enhancing Learning Transfer. New Directions for Adult and Continuing Education, 2013(137), 27-38. https://doi.org/10.1002/ace.20042

Jenkins, J. (2012). English as a Lingua Franca from the classroom to the classroom. ELT Journal, 66(4), 486-494.

Johnson, S. and Veitch, S. and Dewiyanti, S. (2015). A framework to embed communication skills across the curriculum: A design-based research approach. Journal of University Teaching and Learning Practice, 12(4), 6.

Kachru, B. B. (1992). Teaching world englishes. The other tongue: English across cultures (2nd ed). University of Illinois Press.

Kebede, D. (2014). The implementation of language skills integration In English as a foreign language (EFL) classes: Jimma college of teachers' education in focus. In Jimma University 92. Jimma University.

King, J. (2002). Using DVD features Films in the EFL Classroom. The Weekly Column, 15(5), 509-523.

Klassen, A. F., Gulati, S., Granek, L., Rosenberg-Yunger, Z. R., Watt, L., Sung, L., ... \& Shaw, N. T. (2012). Understanding the health impact of caregiving: a qualitative study of immigrant parents and single parents of children with cancer. Quality of Life Research, 21(9), 1595-1605.

Klein, J. I., Taveras, S., King, S. H., Commutante, A., Bey, L. C., \& Strupling, B. (2009). Project Based learning: new and updated resources for social studies and science exit project. NYC Department of Education.

Kondo-Brown, K. (2005). Differences in language skills: Heritage language learner subgroups and foreign language learners. The Modern Language Journal, 89(4), 563581.

Lander, J. A., \& Brown, H. D. (2007). Teaching by Principles: An Interactive Approach to Language Pedagogy. In Language (4 th, Vol. 71, Issue 4). Pearson Longman. https://doi.org/10.2307/415773

Lee, L. Y. K., Lee, J. K. L., Wong, K. F., Tsang, A. Y. K., \& Li, M. K. (2010). The establishment of an integrated skills training centre for undergraduate nursing education. International Nursing Review, 57(3), 359-364. https://doi.org/10.1111/j.1466$7657.2009 .00796 . x$

Leung, C. (2013). Communication and participatory involvement in linguistically diverse classrooms. In The Multilingual Turn (p. 133-156). Routledge.

Lewallen, T. C., Hunt, H., Potts-Datema, W., Zaza, S., \& Giles, W. (2015). The Whole School, Whole Community, Whole Child Model: A New Approach for Improving Educational Attainment and Healthy Development for Students. Journal of School Health, 85(11), 729-739. https://doi.org/10.1111/josh.12310 
Lopriore, L., \& Vettorel, P. (2015). Promoting awareness of Englishes and ELF in the English language classroom. In International Perspectives on English as a Lingua Franca (p. 1334). Palgrave Macmillan.

MacVaugh, J., Jones, A., \& Auty, S. (2014). Implicit, stand-alone or integrated skills education for undergraduates: a longitudinal analysis of programme outcomes. Journal of Further and Higher Education, 38(6), 755-772. https://doi.org/10.1080/0309877X.2013.765941

Mardjuki, M. S. (2018). English teachers' perception on the use of authentic assessment in 2013 curriculum. IJELTAL (Indonesian Journal of English Language Teaching and Applied Linguistics), 2(2), 151-163.

Marra, R. M., Jonassen, D. H., Palmer, B., \& Luft, S. (2014). Why problem-based learning works: Theoretical foundations. Journal on Excellence in College Teaching, 25.

McDonough, J., Shaw, C. \& Masuhara, H. (2013). Materials and methods in ELT: A teacher's guide (3 rd). Wiley-Blackwell.

McGrath, D. (2002). Getting started with project-based learning. Learning and Leading with Technology, 30(3), 42-45.

Mekheimer, M. (2011). Effectiveness of an integrated, holistic pedagogy of EFL skills in college students. The Educational Research Journal, 25(100), 41-47.

Min, K. C., Rashid, A. M., \& Nazri, M. I. (2012). Teachers' understanding and practice towards thematic approach in teaching integrated living skills (ILS) in Malaysia. International Journal of Humanities and Social Science, 2(23), 273-281.

Monfared, A., \& Khatib, M. (2018). English or Englishes? Outer and Expanding Circle Teachers' Awareness of and Attitudes towards their Own Variants of English in ESL/EFL Teaching Contexts. Australian Journal of Teacher Education, 43(2), 56-75. https://doi.org/10.14221/ajte.2018v43n2.4

Murphy, S. (2003). Second language transfer during third language acquisition. Studies in Applied Linguistics and TESOL, 3(2).

Nan, C. (2018). Implications of Interrelationship among Four Language Skills for High School English Teaching. Journal of Language Teaching and Research, 9(2), 418. https://doi.org/10.17507/jltr.0902.26

Nanda, M. R. D., Harahap, A., \& Damayanti, I. (2019). An Analysis of Language Skills' Proportions in the English Textbook Grade XII Published by Kemendikbud 2014. Journal of English Education and Teaching, 3(4), 438-451.

Nunan, D. (2004). Task-based language teaching. Cambridge University Press.

Oxford, R. (2001). Integrated skills in the ESL/EFL classroom. The Journal of TESOL France, $8,5-12$.

Oxford, R. (2001). Integrated skills in the ESL/EFL classroom. ERIC Digests, 6(1), 1-7.

Pardede, P. (2019). Integrated skills approach in EFL classrooms. Research Gate Net. Publication, 217-279.

Peregoy, S. F. and Boyle, O. F. (2001). Reading, writing, and learning in ESL: A resource book for $\mathrm{K}-12$ teachers. Addison Wesley Longman.

Plakans, L. (2012). Assessment of Integrated Skills. In The Encyclopedia of Applied Linguistics. Blackwell Publishing Ltd. https://doi.org/10.1002/9781405198431.wbealoo46

Poon, A. Y. (2011). Integrative-Narrative Method: The Role of Narratives, Integrated Skills and Cognitive Strategies in the Teaching of English Listening in Hong Kong. Asia- 
Pacific Education Researcher (De La Salle University Manila), 20(3).

Pysarchyk, O, I., \& Yamshynska, N, V. (2015). The importance of integrating reading and writing for EFL teaching. Advanced Education, 3, 77-83.

Renau, M, L. (2016). A review of the traditional and curent language teaching methods. $A$ Review of the Traditional and Curent Language Teaching Methods, 3(2), 82-88.

Richards, J. C. and Rodgers, T. S. (2001). Approaches and methods in language teaching (2 nd). Cambridge University Press.

Richards, J.C. and Schmidt, R. (2002). Longman dictionary of language teaching and applied linguistics ( $3 \mathrm{rd}$ ). Pearson Education Limited.

Roberts, L., \& Kellough, D. (2000). A guide for developing interdisciplinary thematic units (2 nd). Merrill.

Robson, M. (2002). Problem-solving in Groups. Gower Publishing Limited.

Ruwe, K., McLaughlin, T.F., Derby, K. M., Johnson, K. (2011). The multiple effects of direct instruction flashcards on sight word acquisition, passage reading and errors for three middle school students with intellectual disabilities. Journal of Developmental and Physical Disabilities, 2(3), 241-255.

Rymes, B. (2015). Classroom discourse analysis: A tool for critical reflection. Routledge.

Sadiku, L. M. (2015). The Importance of Four Skills Reading, Speaking, Writing, Listening in a Lesson Hour. European Journal of Language and Literature, 1(1), 29. https://doi.org/10.26417/ejls.v1i1.p29-31

Saldaña, J. (2015). The coding manual for qualitative researchers. Sage.

Sands, R.G., \& Solomon, P. (2003). Developing educational groups in social work practice. Journal Scholarly Commons Paper, 26(2), 5-21.

Sari, I. N. (2017). The Influence of Motivation and Learning, Teaching Methods and Means of Education Student Achievement. Sinergi: Jurnal Ilmiah Ilmu Manajemen, 6(2).

Sevy-Biloon, J. (2018). Integrating EFL skills for authentically teaching specific grammar and vocabulary. Studies in English Language and Education, 5(2), 175-184. https://doi.org/10.24815/siele.v5i2.9705

Skehan, P. (2001). Tasks and language performance. Researching Pedagogic Tasks: Second Language Learning, Teaching, and Testing, 167-186.

Spector, J. M. (2015). Foundations of educational technology: Integrative approaches and interdisciplinary perspectives. Routledge.

Su, C. Y. (2007). Students' changing views and the integrated-skills approach in Taiwan's EFL college classes. Journal Education Research Institute, 8(1), 27-40.

Tajzad, M. Namaghi, S. A. O. (2014). Exploring EFL learners' perceptions of integrated skills approach: A grounded theory. Journal English Language Teaching, 7(11), 92-98. https://doi.org/10.5539/elt.v7n11p92

Tanjung, F. Z. (2018). Language Learning Strategies In English As A Foreign Language Classroom In Indonesian Higher Education Context. Language and Language Teaching Journal, 21(Supplement), 50-68. https://doi.org/10.24071//lt.2018.Suppl2106

Tavil, M. Z. (2010). Integrating listening and speaking skills to facilitate English language learners' communicative competence. Procedia Social and Behavioral Sciences, 9(0), 765-770. https://doi.org/10.1016/j.sbspro.2010.12.231

Thomas, J. W. (2000). A review of research on project-based learning. http://www.bie.org/research/study/review_of_project_based_learning_2000\%oA\%oA Tsung-Yuan, H. \& Oxford, R. (2002). Comparing theories of language learning Strategies: A 
Saiful Akmal, et al.

Confirmatory Factor Analysis. The Modern Language Journal, 86(3), 368-383.

Tuncay, H. (2014). An integrated skills approach using feature movie in EFL at tertiary level. The Turkish Online Journal of Education Technology, 13(1), 56-63.

Urquhart, C. (2012). Grounded theory for qualitative research: A practical guide. Sage.

Yang, Y. (2011). On cultivation of cross-cultural awareness in college English teaching: Take integrated skills of English as an example. Canadian Social Science, 7(2), 110-116.

Yimwilai, S. (2015). An Integrated Approach to Teaching Literature in an EFL Classroom. English Language Teaching, 8(2). https://doi.org/10.5539/elt.v8n2p14

Zepke, N., \& Leach, L. (2010). Improving student engagement: Ten proposals for action. Active Learning in Higher Education, 11(3), 167-177. https://doi.org/10.1177/1469787410379680 